\author{
Marek Kuźniak \\ Uniwersytet Wrocławski \\ kuzniak@uni.wroc.pl
}

\title{
EGZAMIN NA TŁUMACZA PRZYSIĘGŁEGO W ŚWIETLE TZW. KRZYWEJ GAUSSA
}

DOI: http://dx.doi.org/10.12775/RP.2017.013

Zarys treści: W artykule podjęto problematykę oceny wyników egzaminu na tłumacza przysięgłego. Analiza oparta jest o dane statystyczne, do interpretacji których wykorzystano krzywą Gaussa. Autor artykułu zakłada, że wyniki wszelkich egzaminów, w tym również egzaminów państwowych, podlegają nieubłaganym prawom statystyki, a wszelkie odchylenia niestandardowe powinny prowadzić do ustalenia ich przyczyn i podjęcia środków naprawczych. Analizie poddano wyniki egzaminów 574 kandydatów na tłumacza przysięgłego 24 różnych języków. W swojej konkluzji autor zauważa, że wyniki egzaminów nie odbiegają znacząco od normy wyznaczonej krzywą Gaussa, choć w przypadku egzaminu pisemnego sugeruje delikatną korektę oceniania.

Słowa kluczowe: egzamin na tłumacza przysięgłego, krzywa Gaussa, zdawalność

\section{Wstęp}

Droblematyka wyników liczbowych egzaminu na tłumacza przysięgłego do tej pory nie była przedmiotem analiz o charakterze statystycznym w perspektywie glottodydaktycznej. Sprawa jest istotna, ponieważ zakłada się, że wyniki egzaminów, które stanowią zwieńczenie określonego etapu edukacyjnego, podlegają nieubłaganym prawom statystyki, a wszelkie odchylenia niestandardowe należy traktować jako przyczynek do przedsięwzięcia środków naprawczych. Takie podejście stosuje się na uczelniach, gdzie wymóg krzywej Gaussa w osiąganiu ocen przedmiotowych jest traktowany jako wzorzec właściwego sposobu ewaluacji, a tym samym osiągania określonych standardów zapewniania jakości kształcenia w świetle wymogów Polskiej Komisji Akredytacyjnej. 
Egzamin na tłumacza przysięgłego jest jednak nieco innym egzaminem od sposobów weryfikowania wiedzy i umiejętności w systemie zinstytucjonalizowanym, jak np. w szkolnictwie średnim czy wyższym. To egzamin, który nie jest poprzedzony żadnym obowiązkowym kursem przygotowującym, którego zaliczenie stanowiłoby podstawę dopuszczenia do egzaminu. Specyfikę egzaminu na tłumacza przysięgłego regulują odpowiednie akty normatywne. Tendencje deregulacyjne w polityce prowadzonej przez Ministerstwo Sprawiedliwości po wprowadzeniu nowelizacji Ustawy o zawodzie tłumacza przysięgłego doprowadziły do ułatwień, jeśli chodzi o warunki, jakie powinien spełniać kandydat wnioskujący o egzamin. Pytanie, czy warunki te można określić jako brzegowe w takim rozumieniu, w jakim występują one np. przy przystępowaniu do egzaminów na uczelni, gdzie student zostaje dopuszczony do egzaminu po spełnieniu ściśle określonych wymogów przewidzianych programem studiów. Zapewne nie, zważywszy na fakt, że jest przecież możliwa sytuacja, w której osoba spełniła ustawowo wszystkie wymogi formalne, a do egzaminu jest zupełnie nieprzygotowana od strony merytorycznej. Odmienną kwestią jest to, czy kandydatowi przysługuje prawo do wszczęcia procedury odwoławczej od wyniku egzaminu na tłumacza. Rodzi się również zasadnicze pytanie, czy krzywa Gaussa w rozumieniu oceny poprawności wyników prac egzaminacyjnych jest w przypadku przedmiotowego egzaminu zasadna. Jeśli tak, to co wynika $\mathrm{z}$ zastosowania tego statystycznego narzędzia dla poczynienia systematycznej refleksji nad oceną egzaminu jako swoistej cezury do uzyskania „licencji” w zakresie wykonywania zawodu tłumacza, szczególnie w przypadku potencjalnych odchyleń od oczekiwanego standardu? Jeśli nie, to w oparciu o jakie narzędzia taką refleksję poczynić? Próba odniesienia do powyżej postawionych problemów zostanie podjęta w niniejszym artykule.

\section{Struktura artykułu}

Niniejszy artykuł składa się z dwóch części. W części pierwszej - sprawozdawczej - spróbuję zdefiniować termin „egzamin”, co będzie ściśle związane $z$ odpowiedzią na pierwsze $z$ postawionych pytań, tj. pytanie o wszczęcie ewentualnej procedury odwoławczej; w części drugiej - analitycznej - spróbuję skorzystać z narzędzia, jakim jest krzywa Gaussa, w celu interpretacji wyników egzaminu na tłumacza przysięgłego z równoczesną oceną jej zasadności odnośnie do tego rodzaju ustawowo określonej weryfikacji kompetencji kandydata. 


\section{Egzamin - definicje oraz implikacje}

Przedmiotowe rozważania rozpocznę od wątpliwości natury proceduralnej związanej z egzaminem na tłumacza, a mianowicie, czy użycie terminu „egzamin” zobowiązuje podmiot przeprowadzający go do zorganizowania terminu poprawkowego. Egzamin na tłumacza przysięgłego został opisany $\mathrm{w}$ ustawie o zawodzie tłumacza przysięgłego oraz $\mathrm{w}$ odnośnych rozporządzeniach ${ }^{1}$. Przywołane źródła legislacyjne nie definiują samego pojęcia, natomiast szczegółowo określają sposób przeprowadzenia egzaminu niejako indukcyjne (oddolnie) albo ściślej - intensjonalnie, charakteryzując w ten sposób rozumienie pojęcia „egzamin”. Próbując jednak uznać pojawiające się wątpliwości odnośnie do interpretacji samego terminu jako ważne zarówno z perspektywy formalno-prawnej, jak i czysto poznawczej, dokonałem przeglądu źródeł „popularnych” oraz „prawodawczych” w celu określenia, czy istnieją podstawy do zgłaszania przedmiotowych wątpliwości, a z drugiej strony, czy egzamin jest terminem nacechowanym z punktu widzenia legislacyjnego, co również rodziłoby określone skutki w przypadku odpowiedzi pozytywnej.

\subsection{Egzamin - perspektywa popularna}

$\mathrm{Na}$ stronach popularnej encyklopedii internetowej termin „egzamin” (łac. examen - badanie) - jest pojmowany jako ,jedna $\mathrm{z}$ form sprawdzania wiedzy. Stosuje się ją wielu typach szkół, w tym głównie w szkołach wyższych, a także $\mathrm{w}$ innych instytucjach, np. w ramach rekrutacji na stanowiska w urzędach państwowych albo weryfikacji kandydatów na duchownych"2.

Dalej na stronach wspomnianej encyklopedii czytamy: „W klasyfikacji systemów egzaminacyjnych wyróżnia się

1 Ustawa z dnia 25 listopada 2004 r. o zawodzie tłumacza przysięgłego (Dz. U. 2004 nr 273 poz. 2702).

Ustawa z dnia 12 maja 2006 r. o zmianie ustawy o zawodzie tłumacza przysięgłego (Dz. U. z 2006 r. nr 107, poz. 722).

Rozporządzenie Ministra Sprawiedliwości z dnia 24 stycznia 2005 r. w sprawie szczegółowego sposobu przeprowadzenia egzaminu na tłumacza przysięgłego (Dz. U. $2005 \mathrm{nr}$ 15, oz. 129).

Rozporządzenie Ministra Sprawiedliwości z dnia 24 stycznia 2005 r. w sprawie Państwowej Komisji Egzaminacyjnej do przeprowadzania egzaminu na tłumacza przysięgłego (Dz. U. 2005 nr 15, poz. 127).

${ }^{2}$ http://pl.wikipedia.org/wiki/Egzamin (dostęp: 22 kwietnia 2015 r.). 
- egzaminy zewnętrzne (to takie, których wyniki poddawane są ocenie nauczycieli z innych szkół niż ta, w której odbył się dany egzamin);

- egzaminy wewnętrzne (przeprowadzane przez nauczycieli danej szkoły; różnego rodzaju kartkówki, sprawdziany, kolokwia);

- sprawdzian - szerokie pojęcie stosowane na określenie różnego typu działań mających na celu weryfikację wiedzy, stanu rzeczy itp."3.

Warto przytoczyć również bardziej 'specjalistyczne' rozumienie terminu „egzamin" 4

„Sprawdzenie wiedzy teoretycznej i umiejętności praktycznych w formie egzaminu państwowego stosuje się $\mathrm{w}$ dziedzinach, gdzie przepisy wymagają posiadania konkretnych uprawnień. Na przykład egzamin na prawo jazdy określonej kategorii (teoretyczny i praktyczny), egzamin dla kandydatów na instruktorów/wykładowców nauki jazdy; egzamin dla kandydatów na tłumaczy przysięgłych; egzaminy w ramach specjalizacji lekarskich, itp.".

Pobieżna lektura wyżej przytoczonych passusów ukazuje w zasadzie wykluczające się na poziomie konceptualnym użycia terminów „egzamin” oraz „sprawdzian” w popularnym dyskursie. Wydaje się, że „sprawdzian” jest terminem bardziej ogólnym, natomiast „egzamin” stanowi wyższą formę uszczegółowienia w paradygmatycznym układzie pojęciowym, a co za tym idzie - zakresowo jest raczej zawężony do ponadlicealnego szczebla edukacji lub stanowi człon nominalny w sytuacji wyspecjalizowanych obszarów wiedzy, jak np. tytułowy egzamin na tłumacza przysięgłego. Powyższe wydaje się z kolei kontrintuicyjne na szczeblu edukacji niższego poziomu niż uniwersytecki, gdzie „egzamin” stanowi formę sumarycznej weryfikacji wiedzy, natomiast „sprawdziany” mają charakter bardziej punktowy, weryfikujący szczegółowe obszary wiedzy. Konkludując, oba terminy w potocznym, tutaj „popularnym”, rozumieniu są w zasadzie wariantywne, co nie oznacza tzw. synonimii pełnej, gdyż lokalnie zapewne wystąpią silne tendencje co do łączliwości wyrazowej jednego albo drugiego terminu. Przykładowo, w kontekście weryfikacji wiedzy na szczeblu licealnym czy gimnazjalnym powiemy zdecydowanie częściej o „egzaminie maturalnym” oraz „egzaminie gimnazjalnym”, a nie na przykład o „sprawdzianie”. Natomiast w przypadku szczebla podstawowego będzie odwrotnie: mówimy częściej o „sprawdzianie szóstoklasisty” aniżeli o „egzaminie szóstoklasisty”, co jednoznacznie potwierdzają dane w Narodowym Korpusie Języka Polskiego.

${ }^{3}$ http://pl.wikipedia.org/wiki/Sprawdzian_(egzamin) (dostęp: 22 kwietnia 2015 r.).

4 http://pl.wikipedia.org/wiki/Egzamin (dostęp: 22 kwietnia 2015 r.). 


\subsection{Egzamin - perspektywa prawodawcza}

Jeśli chodzi o perspektywę legislacyjną, a więc próbę uściślenia terminu „egzamin", zarówno w aktach normatywnych publikowanych na stronach ministerstwa sprawiedliwości, jak i ministerstwa nauki i szkolnictwa wyższego oraz ministerstwa edukacji narodowej, to podstawowy wniosek dotyczy braku tzw. definicji ekstensjonalnej przedmiotowego terminu. Próba precyzacji, jak zaznaczono powyżej, odbywa się w drodze uszczegółowienia na poziomie intensjonalnym, co w tym przypadku oznacza omówienie trybu oraz warunków przeprowadzenia egzaminu, pozostawiając sam termin „egzamin” niedookreślonym. Na przykład w świetle Ustawy z dnia 25 listopada 2004 roku o zawodzie tłumacza przysięgłego (Dz. U. z dnia 27 grudnia 2004 r.), artykuł 4., pkt. 1 otrzymuje następujące brzmienie:

Art. 4. 1. Egzamin ${ }^{5}$ na tłumacza przysięgłego składa się z dwóch części:

1) tłumaczenia pisemnego, z języka polskiego na język obcy oraz z języka obcego na język polski;

2) tłumaczenia ustnego, z języka polskiego na język obcy oraz z języka obcego na język polski.

2. Egzamin na tłumacza przysięgłego uważa się za zdany w przypadku uzyskania pozytywnych ocen z obu części egzaminu wskazanych w ust. 1.

3. ${ }^{(3)}$ (uchylony).

4. Koszty egzaminu, w tym opłatę egzaminacyjną, ponosi kandydat na tłumacza przysięgłego.

5. Opłata egzaminacyjna stanowi dochód budżetu państwa.

6. Minister Sprawiedliwości określi, w drodze rozporządzenia, wysokość opłaty egzaminacyjnej ponoszonej przez kandydata na tłumacza przysięgłego, biorąc pod uwagę rzeczywiste koszty organizacji i przeprowadzenia egzaminu.

7. Minister Sprawiedliwości określi, w drodze rozporządzenia, szczegółowy sposób przeprowadzenia egzaminu w części pisemnej i ustnej, z uwzględnieniem obowiązku sprawdzenia umiejętności tłumaczenia pism sądowych i urzędowych oraz tekstów prawniczych.

Podobnie w rozporządzeniu ministra sprawiedliwości z dnia 24 stycznia 2005 roku w sprawie Państwowej Komisji Egzaminacyjnej do przeprowadzania egzaminu na tłumacza przysięgłego (Dz. U. z dnia 26 stycznia 2005 r.) termin „egzamin” nie jest zdefiniowany per se, a tylko przywołany, oczywi-

\footnotetext{
${ }^{5}$ Podkreślenia w przywoływanych aktach normatywnych moje - M.K.
} 
ście w domniemaniu, jako termin, który należy czytać w kontekście prawnym określonego aktu normatywnego. Mamy zatem lakoniczną wzmiankę:

$\$$ 3. Przewodniczący Komisji kieruje pracami Komisji oraz zapewnia prawidłowe przygotowanie i przeprowadzenie egzaminu na tłumacza przysięgłego, zwanego dalej „egzaminem”,

Wzmianka ta odnosi do innego rozporządzenia ministra sprawiedliwości, tym razem z dnia 24 stycznia 2005 roku w sprawie szczegółowego sposobu przeprowadzenia egzaminu na tłumacza przysięgłego (Dz. U. z dnia 26 stycznia 2005 r.) Dz.U.05.15.129, gdzie czytamy:

$\$ 1$. Egzamin na tłumacza przysięgłego, zwany dalej „egzaminem”, jest przeprowadzany przez zespół egzaminacyjny wyznaczony przez Przewodniczącego Państwowej Komisji Egzaminacyjnej, zwanego dalej „Przewodniczącym Komisji”, zgodnie z przepisami o trybie działania Państwowej Komisji Egzaminacyjnej.

(...)

2. Część pisemna egzaminu polega na tłumaczeniu 4 tekstów:

1) dwóch z języka polskiego na język obcy, w tym jednego, który jest pismem sądowym, urzędowym albo tekstem prawniczym;

2) dwóch z języka obcego na język polski, w tym jednego, który jest pismem sądowym, urzędowym albo tekstem prawniczym.

(...)

5. Na pracy pisemnej kandydatowi nie wolno umieszczać swojego nazwiska ani żadnych innych danych pozwalających ustalić jego tożsamość.

$\$$ 8. 1. Po przeprowadzeniu części pisemnej egzaminu zespół egzaminacyjny ustala jego wynik, stanowiący sumę punktów przyznawanych za następujące elementy oceny, osobno, każdego z 4 tekstów:

(...)

2. Maksymalna liczba punktów możliwa do uzyskania przez kandydata z części pisemnej egzaminu wynosi 200 punktów.

3. Ocenę pozytywną z części pisemnej egzaminu otrzymuje kandydat, który uzyskał co najmniej 150 punktów.

$\$$ 10. 1. Część ustna egzaminu polega na tłumaczeniu:

1) konsekutywnym (egzaminator odczytuje lub odtwarza tekst z przerwami na tłumaczenie) z języka polskiego na język obcy dwóch tekstów, w tym jednego, który jest pismem sądowym, urzędowym albo tekstem prawniczym;

2) a vista (kandydat otrzymuje do tłumaczenia tekst $w$ formie pisemnej) $z$ języka 
obcego na język polski dwóch tekstów, w tym jednego, który jest pismem sądowym, urzędowym albo tekstem prawniczym.

2. Teksty do tłumaczenia a vista wręczane są kandydatowi bezpośrednio przed tłumaczeniem.

3. Część ustna egzaminu jest utrwalana za pomocą urządzeń rejestrujących dźwięk. $\$$ 11. 1. Po przeprowadzeniu części ustnej egzaminu zespół egzaminacyjny ustala jego wynik, stanowiący sumę punktów przyznawanych za następujące elementy oceny, osobno, każdego z 4 tekstów:

(...)

2. Maksymalna liczba punktów możliwa do uzyskania przez kandydata z części ustnej egzaminu wynosi 200 punktów.

3. Ocenę pozytywną części ustnej otrzymuje kandydat, który uzyskał co najmniej 150 punktów.

Tyle sama Ustawa o zawodzie tłumacza przysięgłego. Jeśli natomiast chodzi o ustawę o szkolnictwie wyższym ${ }^{6}$, to nie definiuje ona również terminu „egzamin”. W Ustawie wymienia się natomiast różne rodzaje egzaminów, np.: dyplomowe, wstępne, maturalne. Art. 168b.1. przedmiotowej Ustawy przywołuje natomiast termin „postępowanie egzaminacyjne” w kontekście uzyskania uprawnień do wykonywania zawodu: „Uczelnia może prowadzić studia we współpracy z organem nadającym uprawnienie do wykonywania zawodu, organem przeprowadzającym postępowanie egzaminacyjne w ramach uzyskiwania uprawnień do wykonywania zawodu, organem samorządu zawodowego, organizacją gospodarczą lub organem rejestrowym”. Abstrahując od kontekstu cytowanego artykułu, można by zaryzykować twierdzenie, że egzamin na tłumacza przysięgłego stanowi de facto postępowanie egzaminacyjne, nie jest zaś egzaminem w rozumieniu przywołanej w przypisie 6. Ustawy o szkolnictwie wyższym. Ponieważ jednak sam termin „postępowanie” wprowadza silne konotacje co do trybu administracyjnego egzaminu w świetle kodeksowym, a tak de jure nie jest ${ }^{7}$, zatem i to

${ }^{6}$ Ustawa z dnia 18 marca 2011 r. o zmianie ustawy - Prawo o szkolnictwie wyższym, ustawy o stopniach naukowych i tytule naukowym oraz o stopniach i tytule w zakresie sztuki oraz o zmianie niektórych innych ustaw.

7 Patrz postanowienie Wojewódzkiego Sądu Administracyjnego w Warszawie z dnia 20 maja 2015 r., (sygn. akt VI SAB/Wa 40/14) w sprawie trybu przeprowadzenia egzaminu na tłumacza przysięgłego w kwestii dotyczącej ewentualnego obowiązku wydania decyzji na piśmie ustalającej wynik przedmiotowego egzaminu. Obowiązek wydania takiej decyzji zrodziłby określone skutki prawne, a ściślej otworzyłby drogę do wszczęcia procedur odwoławczych od 
określenie trzeba uznać za nieadekwatne w przypadku egzaminu na tłumacza przysięgłego.

Wreszcie Ustawa z dnia 25 lipca 1998 roku o zmianie ustawy o systemie oświaty (Dz.U. nr 117 poz.759), a konkretnie art. 3. ust. 21, mówi o egzaminie „potwierdzającym kwalifikacje w zawodzie - należy przez to rozumieć egzamin umożliwiający uzyskanie dyplomu potwierdzającego kwalifikacje zawodowe lub świadectwa potwierdzającego kwalifikację w zawodzie - jeżeli został przeprowadzony w zakresie jednej kwalifikacji". Regulamin przeprowadzenia państwowego egzaminu specjalizacyjnego zatwierdzony przez Ministra Zdrowia w dniu 7 stycznia 2004 roku spełnia np. wymóg cytowanego wyżej przepisu prawnego w odniesieniu do „egzaminu państwowego dla pielęgniarek i położnych po odbyciu specjalizacji w określonej dziedzinie pielęgniarstwa lub dziedzinie mającej zastosowanie w ochronie zdrowia”. Definicja ta zresztą po części pokrywa się z charakterystyką formalno-prawną egzaminu na tłumacza przysięgłego, choć pozytywny wynik nie kończy się uzyskaniem dyplomu, licencji, a „tylko" świadectwem (zaświadczeniem) wydanym przez Ministra Sprawiedliwości, które uprawnia do wykonywania tłumaczeń po uprzednim złożeniu ślubowania oraz uzyskaniem wpisu na listę tłumaczy przysięgłych prowadzoną przez Ministra Sprawiedliwości.

Konstatując, Ustawa z dnia 25 lipca 1998 roku o zmianie ustawy o systemie oświaty nie określa również samej definicji egzaminu. Co ciekawe jednak, wymienia jako w zasadzie synonimiczny termin „sprawdzian”, tak jak dzieje się to w przypadku przytoczonego wyżej rozumienia potocznie rozumianego terminu.

W tej chwili można jeszcze bardziej sprecyzować pierwsze z pytań sformułowanych na wstępie, a mianowicie: czy istnieją podstawy prawne do wnoszenia o tzw. termin poprawkowy z samego faktu nazwania czynności sprawdzających wiedzę kandydata na tłumacza „egzaminem”? Odpowiedź i w tym przypadku jest negatywna, a dzieje się tak dlatego, że nie istnieje ścisłe w sensie prawnym określenie samego pojęcia „egzaminu”, a wszelka precyzacja odbywa się na poziome poszczególnych aktów prawodawczych oraz wykonawczych, a także dokumentów niższej rangi, jak statuty, uchwały, czy

wyników uzyskanych na egzaminie. Wojewódzki Sąd Administracyjny w swym postanowieniu podtrzymał wniosek Ministra Sprawiedliwości o oddalenie żądania skarżącego jako niedopuszczalne na mocy obowiązujących przepisów prawa. Postanowienie WSA nie pozostawia zatem wątpliwości, że wynik egzaminu na tłumacza przysięgłego nie podlega zaskarżeniu. W tym miejscu chciałbym podziękować Naczelnikowi Wydziału Tłumaczy Przysięgłych, Panu Bolesławowi Cieślikowi, za udostępnienie dokumentu. 
regulaminy uczelni wyższych ${ }^{8}$. I tak, na przykład, brak eksplicytnie wyrażonych zapisów w Ustawie o zawodzie tłumacza przysięgłego umożliwiających ewentualne procedury odwoławcze czyni ewentualne skargi w tym zakresie bezprzedmiotowymi lub lepiej - niedopuszczalnymi.

\section{Wyniki egzaminu na tłumacza przysięgłego a krzywa Gaussa}

Odnosząc się jeszcze do pierwszej części rozważań, można pokusić się o pewne wnioski dotyczące samego egzaminu na tłumacza przysięgłego. Po pierwsze, jako taki jest sprawdzianem wiedzy i umiejętności na poziomie ogólnopolskim. Istnieje już dosyć pokaźna literatura przedmiotu, która może stanowić dla kandydatów cenną wskazówkę w przygotowaniu do egzaminu. Przykładowa literatura załączona została w bibliografii. Po drugie, jest to egzamin państwowy ex lege, ponieważ jest przeprowadzany przez powołaną na mocy odpowiedniej ustawy Państwową Komisję Egzaminacyjną. Po trzecie, jako sprawdzian wiedzy i umiejętności zakłada on nabycie odpowiednich kompetencji w toku studiów wyższych II stopnia, a co za tym idzie - uzyskania odpowiedniej liczby punktów ECTS w zakresie istotnej przedmiotowo wiedzy, umiejętności oraz kompetencji społecznych bez względu na miejsce ukończenia studiów. W tym sensie zastosowanie w rozumieniu glottodydaktycznym krzywej Gaussa w celu scharakteryzowania poprawności mechanizmu oceny prac egzaminacyjnych wydaje się w pełni uzasadnione.

\subsection{Krzywa Gaussa w glottodydaktyce}

Krzywa Gaussa w glottodydaktyce ${ }^{9}$ jest narzędziem praktycznie powszechnie wykorzystywanym do oceny prawidłowości oceny wiedzy oraz umiejętności uczniów oraz studentów. Interpretacja osiągnięć studentów przez pryzmat statystycznego rozkładu ocen stanowi nierzadko wymóg powoływanych przez Rady Wydziałów Komisji ds. Zapewniania Jakości Kształcenia. Pozwolę sobie zacytować istotny przedmiotowo passus z przywołanych w przypisie 9. materiałów szkoleniowych:

8 Patrz np. Uchwala nr 30/2012 Senatu Uniwersytetu Wrocławskiego z dnia 25 kwietnia 2012 r. w sprawie Regulaminu studiów w Uniwersytecie Wrocławskim.

9 Fakty przytaczane w tej części oparte są na materiałach ze szkolenia zatytułowanego Prawidłowe ocenianie studentów oraz zasady przyznawania punktów ECTS, przeprowadzonego 20 stycznia dla pracowników Instytutu Filologii Angielskiej przez prof. Annę Michońską-Stadnik. Patrz również Wilczyńska, Michońska-Stadnik (2010: 2012-205); Brown (1993). 
Najczęściej dzieje się tak, że wyniki oscylują wokół średniej statystycznej. W typowych narzędziach sprawdzania efektów kształcenia, które oceniamy według przyjętej na UWr skali ocen, statystycznie najwięcej studentów powinno otrzymać ocenę 3,5/4,0. Aby zachować idealne statystyczne proporcje, ocen niedostatecznych powinno być tyle samo, ile bardzo dobrych, a ocen dostatecznych - tyle samo, co dobrych plus. Wtedy możemy mówić o rozkładzie normalnym wyników, który graficznie przestawia się jako tzw. krzywa Gaussa, lub inaczej krzywa dzwonowa.

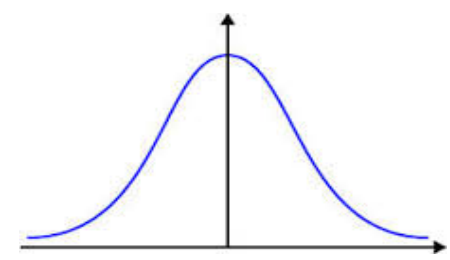

Ryc. 1. Krzywa Gaussa, inaczej zwana krzywą dzwonową ${ }^{10}$

Występują dwa rodzaje skośności: lewo- i prawoskośna. Ta pierwsza występuje wtedy, gdy większość ocen oscyluje w obszarze poniżej średniej w rozkładzie normalnym ocen, natomiast ta druga występuje wtedy, gdy większość ocen oscyluje powyżej wspomnianej średniej. Mówimy wówczas, że mamy albo zbyt wiele słabych ocen (lewoskośność), albo zbyt wiele dobrych (prawoskośność).

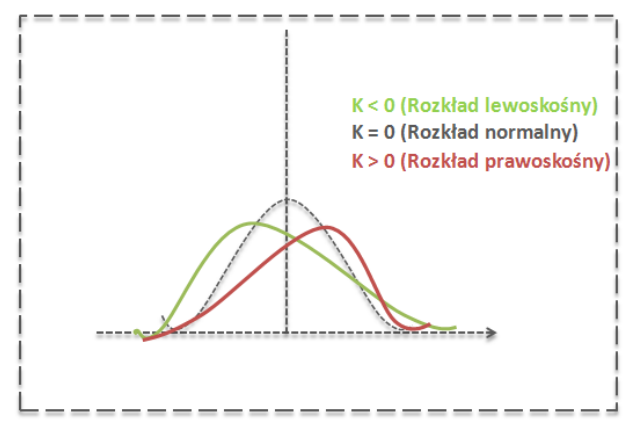

Ryc. 2. Lewoskośność oraz prawoskośność rozkładu wyników ${ }^{11}$

${ }_{10}$ Materiały ze szkolenia zatytułowanego Prawidłowe ocenianie studentów oraz zasady przyznawania punktów ECTS, przeprowadzonego 20 stycznia dla pracowników Instytutu Filologii Angielskiej przez prof. Annę Michońską-Stadnik.

${ }_{11}$ Materiały ze szkolenia zatytułowanego Prawidłowe ocenianie studentów oraz zasady przyznawania punktów ECTS, przeprowadzonego 20 stycznia dla pracowników Instytutu Filologii Angielskiej przez prof. Annę Michońską-Stadnik. 
Glottodydaktycy przyjmują założenie, że rozkład statystyczny ocen z egzaminów winien odzwierciedlać rozkład normalny. Jak argumentują Weronika Wilczyńska oraz Anna Michońska-Stadnik (2010: 202): „(...) jeśli dysponujemy wieloma wynikami, na które składa się szereg drobnych czynników, to najczęściej występujące wyniki oscylują wokół średniej statystycznej (...). Taka chyba jest już ludzka natura, że większość z nas jest przygotowana do egzaminu lub testu raczej przeciętnie niż bardzo dobrze albo wcale, stąd właśnie przewaga ocen/rezultatów przeciętnych". Zatem każde z odchyleń winno, jak się wydaje, skłaniać do refleksji, jeśli chodzi o przyczyny nieproporcjonalnego występowania ocen uzyskiwanych przez daną grupę zdających. Poniżej sprawdzimy, jak powyższe rozważania stosują się do wyników osiąganych podczas egzaminu na tłumacza przysięgłego, zarówno jeśli chodzi o część pisemną, jak i ustną.

\subsection{Wyniki części pisemnej egzaminu na tłumacza przysięgłego w 2014 roku}

Niniejsza część artykułu będzie poświęcona wykorzystaniu tzw. krzywej Gaussa dla określenia na ile tzw. rozkład normalny wyników otrzymywanych na egzaminie jest zgodny z założeniami statystycznymi określonymi dla tego typu sytuacji. Analizie poddano wyniki cząstkowe uzyskane przez 574 kandydatów starających się o uprawnienia w zakresie 24 języków z części pisemnej egzaminu na tłumacza przysięgłego ${ }^{12}$.

Analiza wstępna wykazała, że we wspomnianej grupie 574 osób przystępujących do egzaminu rozbieżność wyników punktowych była znacząca i wynosiła aż 158 pkt., gdzie najsłabszy odnotowany wynik z części pisemnej to 37 pkt., natomiast najlepszy to 195 pkt. Oba te ekstremalne przypadki stanowią względny obszar badań, dla którego - na potrzeby niniejszego artykułu - została stworzona krzywa Gaussa. Wydzielono zatem sześć równych zakresów punktowych:

\begin{tabular}{|l|c|}
\hline Zakres 1 & $37-63$ \\
Zakres 2 & $64-88$ \\
Zakres 3 & $89-114$ \\
Zakres 4 & $115-141$ \\
Zakres 5 & $142-168$ \\
Zakres 6 & $169-195$ \\
\hline
\end{tabular}

Następnie przydzielono wyniki uzyskane z egzaminu pisemnego do każdego z zakresów, co stanowiło podstawę dla krzywej Gaussa:

${ }^{12}$ Składam w tym miejscu podziękowanie p. Monice Alexandre z Wydziału Tłumaczy Przysięgłych Ministerstwa Sprawiedliwości za udostępnienie danych podlegających analizie. 


\begin{tabular}{|l|c|c|}
\hline \multicolumn{1}{|c|}{ Zakres } & Liczba wyników w zakresie & Rozpiętość danego zakresu \\
\hline Zakres 1 & 12 & $37-63$ \\
\hline Zakres 2 & 20 & $64-88$ \\
\hline Zakres 3 & 66 & $89-114$ \\
\hline Zakres 4 & 217 & $115-141$ \\
\hline Zakres 5 & 226 & $142-168$ \\
\hline Zakres 6 & 33 & $169-195$ \\
\hline
\end{tabular}

Widać wyraźnie, że zdecydowana większość wyników mieści się w zakresie 4-5, co zostanie skomentowane poniżej. Podobna procedura została przeprowadzona dla części ustnej.

Warto tutaj przypomnieć, że absolutny zakres punktowy został ustanowiony przez legislatora na poziomie 0-200 pkt. Analiza wstępna wykazała również, co szczególnie istotne dla przedmiotu bieżącej dyskusji, że średnia arytmetyczna wszystkich wyników punktowych wyniosła 136,7 pkt. i stanowi w ten sposób jeden z obszarów odniesienia do interpretacji wyników przedstawionych poniżej w świetle tzw. normalnego rozkładu statystycznego wyników, który został zaznaczony niepogrubioną osią pionową na rysunku poniżej. Drugi istotny obszar odniesienia to wartość 150 pkt., czyli wartości kryterialna, względem której stwierdza się, czy egzamin został zdany, czy nie.

Wyniki egzaminu cząstkowego (pisemny) w świetle krzywej Gaussa wyglądają następująco:

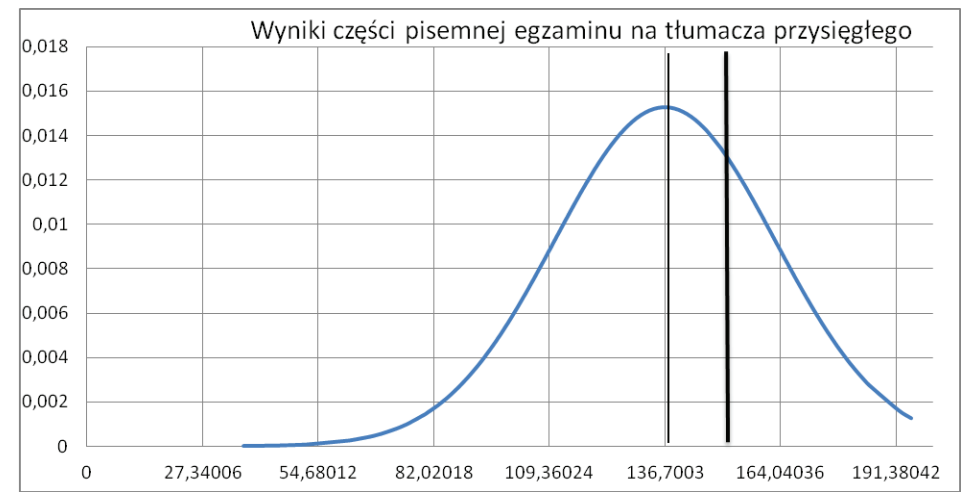

Rys. 3. Wyniki egzaminu cząstkowego (pisemnego) w świetle krzywej Gaussa ${ }^{13}$

${ }^{13}$ Dziękuję w tym miejscu mgr. inż. Ireneuszowi Kuboniowi za pomoc w technicznym opracowaniu wyników. 
Średnia arytmetyczna wszystkich wyników to 136,70 pkt. Potwierdzeniem ważności badawczej obliczonej wartości średniej arytmetycznej jest oczywiście liczba osób uzyskująca wyniki, które Wilczyńska oraz Michońska-Stadnik (2010: 202) opisują jako „oscylujące pomiędzy jednym odchyleniem standardowym w górę i jednym odchyleniem standardowym w dół powyżej lub poniżej średniego statystycznego wyniku". Przyjmując zatem za kryterium wartość wspomnianego odchylenia standardowego, czyli w przybliżeniu 26,01 pkt., okazuje się, że w grupie wyników pomiędzy 115-168 pkt. znalazło się aż 443 kandydatów na 574, czyli 77\% ogółu kandydatów, co stanowi tylko $9 \%$ powyżej oczekiwanego poziomu $68 \%$ opisywanego w glottodydaktyce jako poziom idealny czy też referencjalny w rozkładzie normalnym wyników. Widać również wyraźnie, że krzywa dzwonowa, jeśli chodzi o uzyskiwaną punktację z części pisemnej, wykazuje tendencję lewoskośną względem osi stanowiącej wartość progową dla egzaminu pisemnego, czyli 150 pkt. ${ }^{14}$ oznaczonej na Rys. 3 pogrubioną osią pionową. Oznacza to, że dla większości kandydatów egzamin okazał się zbyt trudny. Ważna tutaj wydaje się jednak wartość odchylenia standardowego oraz wysoki odsetek osób znajdujących się w jego obszarze, co z kolei oznacza, że krzywą wyników można uznać za przebiegającą co do istoty w sposób odpowiedni. Oczywiście jest to odpowiedniość względna, ponieważ - jak już wspomniano wyżej - w skali absolutnej osoby uzyskujące wynik poniżej 150 pkt. nie zostają dopuszczone do części ustnej. Wartość odchylenia będzie również istotna przy porównaniu wyników części pisemnej do części ustnej, o czym mowa poniżej.

\subsection{Wyniki części ustnej egzaminu na tłumacza przysięgłego w 2014 roku}

W przypadku wyników części ustnej egzaminu sytuacja wygląda korzystniej z perspektywy kandydatów, ponieważ średnia arytmetyczna ${ }^{15}$ uzyskanych wyników wynosi 145,74 pkt., gdzie najniższa odnotowana wartość punktowa egzaminu ustnego wyniosła 63 pkt., natomiast najwyższa 191 pkt. Biorąc pod uwagę kryterium odchylenia standardowego, które w przypadku części ustnej wyniosło 18,18 pkt., w grupie wyników oscylujących między 129-172 pkt. znalazło się aż 194 kandydatów na 251 dopuszczonych do tej części, co stanowi 77\% ogółu, a więc dokładnie o tę samą wartość procentową więcej jak w przypadku części pisemnej w stosunku do zakładanego poziomu $68 \%$.

14 Zakłada się tym samym, że wspomniana wartość 150 pkt. odpowiada ocenie 3.0 w przyjętej edukacyjnie skali ocen od 2 do 5 .

${ }_{15}$ Średnia statystyczna zaznaczona została niepogrubioną osią pionową na Rys. 4. 
Szczegółowy rozkład wyników w relacji do zakresów punktowych przedstawiony jest poniżej:

\begin{tabular}{|l|c|c|}
\hline \multicolumn{1}{|c|}{ Zakres } & Liczba wyników w zakresie & Rozpiętość danego zakresu \\
\hline Zakres 1 & 4 & $63-84$ \\
\hline Zakres 2 & 4 & $85-106$ \\
\hline Zakres 3 & 33 & $107-128$ \\
\hline Zakres 4 & 94 & $129-150$ \\
\hline Zakres 5 & 100 & $151-172$ \\
\hline Zakres 6 & 16 & $173-191$ \\
\hline
\end{tabular}

Na Rys. 4 widać z kolei wyraźnie, że obie osie (średniej oraz progowa) są stosunkowo blisko siebie (rozbieżność 4,26 pkt.), co generalnie świadczy o tendencji do uzyskiwania lepszych wyników z części ustnej w stosunku do części pisemnej, gdzie ta rozbieżność wynosi (13,30 pkt.). Warto również zaznaczyć, że w przypadku części ustnej wartość odchylenia standardowego w porównaniu do części pisemnej jest niższa. Oznacza to, że wyniki egzaminu ustnego są bardziej zagęszczone wokół średniej arytmetycznej, zatem ja-

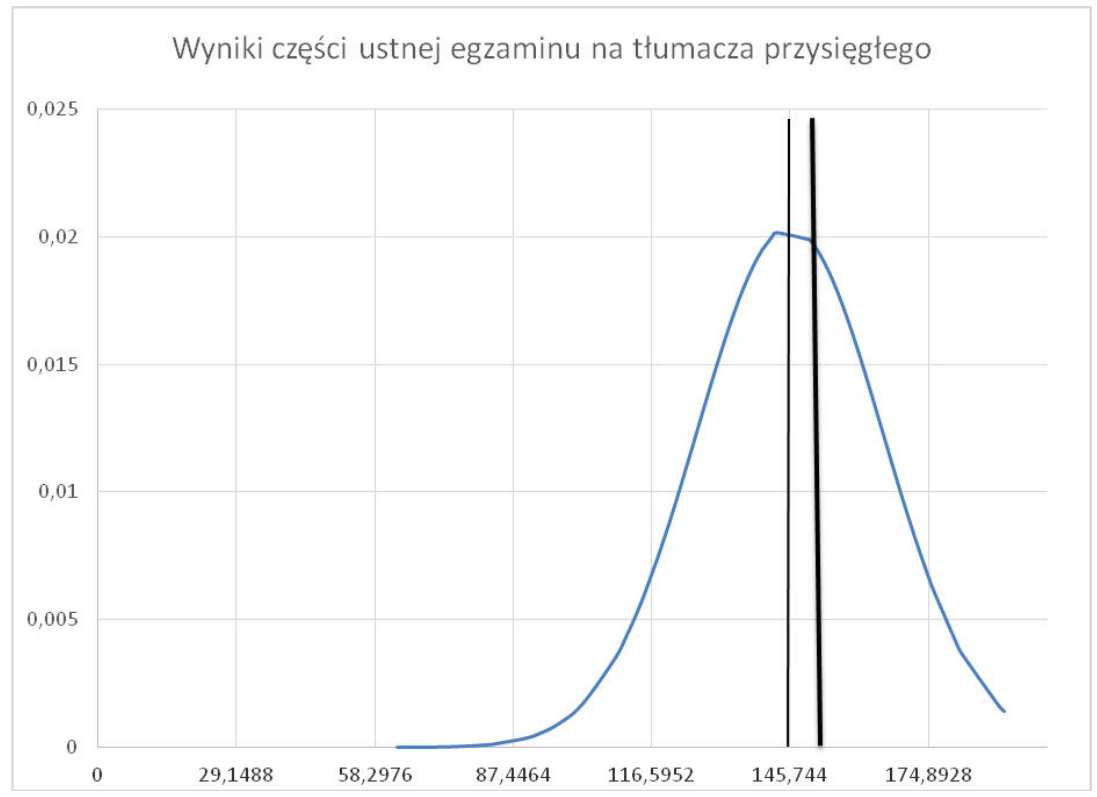

Rys. 4. Wyniki egzaminu cząstkowego (ustnego) w świetle krzywej Gaussa 
wią się niemal jako optymalne z punktu widzenia tzw. rozkładu normalnego osiągnięć kandydata.

Dla porządku statystycznego należy dodać, że największą popularnością wśród kandydatów cieszy się, co raczej nie stanowi niespodzianki, język angielski (około $48 \%$ wszystkich aplikacji). Kolejne języki mające znaczący procentowy udział w egzaminach to język niemiecki (17\%), język rosyjski (12\%), język francuski (6\%) oraz język hiszpański (5\%). Wiodąca rola języka angielskiego jest zatem niekwestionowana. Odzwierciedleniem tego stanu rzeczy jest popyt na publikacje związane z praktyczna stroną egzaminu przede wszystkim wśród adeptów studiów filologicznych ze specjalizacją translatorską, natomiast próbą odpowiedzi na to zapotrzebowanie jest seria „Egzamin na tłumacza przysięgłego w praktyce" ukazująca się nakładem oficyny wydawniczej C.H. Beck (Myrczek-Kadłubicka 2014, 2015; Kuźniak 2013) ${ }^{16}$.

Jak widać zatem na Rys. 4, rozkład wyników wykazuje minimalnie prawoskośną tendencję, co oznacza, że wyniki części ustnej są nieco zawyżone - inaczej niż w przypadku części pisemnej, którą w świetle interpretacji glottodydaktycznej należy uznać za statystykę mniej korzystną z punktu widzenia kandydata, tj. wykazującą większą lewoskośność, ale też w dużej mierze mieszczącą się w ramach obliczonego odchylenia standardowego w górę oraz w dół względem średniej arytmetycznej. Procentowo wyrażone wartości zdawalności wyrażone w skali bezwzględnej (próg 150 pkt.) wyglądają zatem odpowiednio; i tak część pisemną egzaminu na tłumacza przysięgłego zdało w 2014 roku 44\% ogółu kandydatów, natomiast część ustną 59\% kandydatów dopuszczonych do tej części, co stanowi 26\% ogółu kandydatów przystępujących do egzaminu.

\section{Podsumowanie}

Wyniki analizy statystycznej wyników części zarówno pisemnej, jak i ustnej egzaminu na tłumacza przysięgłego potwierdzają generalną adekwatność sposobu oceniania prac egzaminacyjnych przez członków oraz konsultantów Państwowej Komisji Egzaminacyjnej, gdzie około 77\% wszystkich wyników punktowych mieści się w granicach odchylenia standardowego. Jeśli w ogóle Państwowa Komisja Egzaminacyjna miałaby wyciągnąć jakieś określone wnioski, to takie, że wyniki części pisemnej wykazują nieznaczną tenden-

\footnotetext{
${ }^{16}$ Patrz również poczytne książki w dziedzinie właściwego czytania rozumienia umów cywilno-prawnych, ale również sądowych (Berezowski 2008 oraz Berezowski 2011).
} 
cję do zbyt „surowego” oceniania, natomiast sposób weryfikacji wiedzy oraz umiejętności w części ustnej wygląda na statystycznie wręcz optymalny. Wniosek mógłby być taki, że próg zdawalności w przypadku egzaminu pisemnego - przy zachowaniu obecnego rygoru w systemie oceniania - powinien wynosić mniej więcej 140 pkt., natomiast w przypadku egzaminu ustnego próg zdawalności powinien zostać utrzymany na poziomie 150 pkt. Oczywiście sformułowany wniosek należy potraktować jako „miękki” postulat stanowiący wypadkową dokonanej analizy statystycznego rozkładu wyników.

Istotnym kontrargumentem dla obniżenia progu zdawalności byłaby kwestia konsekwencji karnych oraz społecznych wadliwie wykonanych tłumaczeń poświadczonych ${ }^{17}$. Sprawą natomiast otwartą $\mathrm{w}$ perspektywie ewentualnej nowelizacji przepisów pozostaje podnoszone przez środowiska zrzeszające tłumaczy zagadnienie dotyczące rozdzielenia kompetencji w zakresie tłumaczeń pisemnych oraz ustnych, tak aby uprawnienia były przyznawane osobno. Kwestia ta jest wielopłaszczyznowa. Rozdział kompetencji wydaje się poparty z jednej strony badaniami psycholingwistycznymi, natomiast $\mathrm{z}$ drugiej jest kontrargumentowany wątpliwościami o charakterze społeczno-organizacyjnym, zgłaszanymi przez organy administracji państwowej. Sprawa jest oczywiście warta oddzielnej publikacji, ale na tym etapie można po prześledzeniu statystyk zdawalności obu części stwierdzić, że mamy do czynienia z pewną prawidłowością, gdzie mniej więcej połowa kandydatów przechodzi część pisemną, a następnie kolejna grupa (dokładnie 58\%) osób dopuszczonych do części ustnej uzyskuje uprawnienia do tłumaczenia poświadczonego. Przy czym osoby z wynikami powyżej 160 pkt. (86 osób na 251 dopuszczonych do tej części), a więc - umownie rzecz ujmując - ze zdecydowanie dobrze zdanym egzaminem pisemnym, przechodzą z powodzeniem część ustną aż w 76\% przypadków. Statystyki te powinny stanowić ważny przyczynek do dyskusji nad zasadnością wzmiankowanych wyżej głosów za rozdziałem kompetencji tłumacza na pisemne oraz ustne.

${ }^{17}$ Jak słusznie zauważa Recenzent niniejszego artykułu, „pozytywnie zdany egzamin uprawnia do wykonywania zawodu obarczonego ogromną odpowiedzialnością. Tłumacz przysięgły błędnie przetłumaczonym komunikatem może pozbawić kogoś wolności, życia czy wiarygodności. Konsekwencje takich tłumaczeń są opisywane w literaturze przedmiotu (por. chociażby: Kubacki 2012; Kubacki 2014; Matulewska 2014; Nagao 2005)”. 


\section{Literatura}

Berezowski, L., 2008, Jak czytać i rozumieć angielskie umowy?, Warszawa.

Berezowski, L., 2011, Jak czytać i rozumieć angielskie dokumenty sądowe w sprawach cywilnych?, Warszawa.

Brown, J.D., 1993, Understanding Research in Second Language Acquisition, Cambridge.

Kubacki, A.D., 2012, Tłumaczenie poświadczone. Status, kształcenie, warsztat i odpowiedzialność tłumacza przysięgłego, Warszawa.

Kubacki, A.D., 2014, „Błąd krytyczny w tłumaczeniach poświadczonych”, [w:] Translationsforschung: Methoden, Ergebnisse, Perspektiven. Studia Translatorica, vol. 5, I. Bartoszewicz, A. Małgorzewicz (red.), WrocławDresden, s. 49-58.

Kuźniak, M., 2013, Egzamin na tłumacza przysięgłego w praktyce. Język angielski. Analiza językowa, Warszawa.

Matulewska, A., 2014, „Horrory tłumaczeniowe czy tłumacze z piekła rodem? czyli kilka słów o efektywności komunikacji interlingwalnej”, Scripta Neophilologica Posnaniensia XIV, s. 101-118.

Myrczek-Kadłubicka, E., 2013, Egzamin na tłumacza przysięłego. Przewodnik po prawie karnym. Język angielski, Warszawa.

Myrczek-Kadłubicka, E., 2014, Egzamin na tłumacza przysięgłego. Przewodnik po prawie cywilnym. Język angielski - prawo rzeczowe i spadkowe, Warszawa.

Nagao, H., 2005. „Sprawa z Melbourne: niewłaściwe tłumaczenie przyczyną oskarżenia o niepopełnione przestępstwa”, przeł. Z. Rybińska, [w:] Lingua Legis 13, s. 3-7.

Wilczyńska, W., Michońska-Stadnik, A., 2010, Metodologia badań w glottodydaktyce, Kraków.

\section{Literatura rekomendowana na stronie Ministerstwa Sprawiedliwości:}

Cieślik, B., Laska, L., Rojewski, M., 2010, Egzamin na tłumacza przysięłłego. Komentarz, teksty egzaminacyjne, dokumenty, Warszawa.

Dostatni, G., 2005, Komentarz do ustawy o zawodzie tłumacza przysięłego, Warszawa.

Iluk, J., Kubacki, A.D., 2006, Wybór polskich i niemieckich dokumentów do ćwiczeń translacyjnych / Auswahl polnischer und deutscher Dokumente für Translationsübungen, Warszawa.Kierzkowska, D., 2002, Tłumaczenie prawnicze, Warszawa. 
Kierzkowska, D., 2011 (red.), Kodeks tłumacza przysiegłego z komentarzem 2011 - publikacja pod auspicjami Polskiego Towarzystwa Tłumaczy Przysieglych i Specjalistycznych, Warszawa.

Kierzkowska, D., Rybińska, Z., 2011, The New Selection of English Documents, Warszawa.

Kierzkowska, D., Poznański, J. (red.), 1996, Dokumenty polskie. Wybór dla tłumaczy sadowych, Warszawa.

Kubacki, A.D., 2008, „Odpowiedzialność zawodowa tłumaczy przysięgłych”, [w:] Język, Komunikacja, Informacja, t. 3, P. Nowak, M. Nowakowski (red.), Poznań, s. 149-161.

Kubacki, A.D., 2009, Klasyfikacje statystyczne w przekładzie na język niemiecki / Die Klassifikationen in deutscher Übersetzung, Warszawa.

Kubacki, A.D., 2011, Neue Auswahl deutschsprachiger Dokumente, Warszawa. Poznański, J., 2007, Tłumacz w postępowaniu karnym, Warszawa.

PN-EN 15038: Usługi tłumaczeniowe. Wymagania dot. świadczenia usług (PKN 2006).

Rybińska, Z., 2011, Teksty egzaminacyjne dla kandydatów na tłumacza przysięgłego, Warszawa.

Kubacki, A.D., 2012, Tłumaczenie poświadczone. Status, kształcenie, warsztat i odpowiedzialność tłumacza przysięgłego, Warszawa.

\section{Examination for sworn translators and interpreters in view of the Gaussian distribution \\ Summary}

The paper addresses the issue of whether the Gaussian distribution function as a statistical tool used in measuring the adequacy of educational achievements may be equally applied to verify the adequacy of assessment criteria, especially 'pass limits' in the context of conducting state examinations for sworn translators and interpreters in Poland. The paper consists of two parts; the first part is descriptive and is a debate over the notion of 'egzamin' in the Polish legal and popular context. This discussion is extended to cover the specificity of the subject-matter examination for sworn translators and interpreters. The second part is analytical and comprises the analysis of the results of the said exam, obtained by 574 candidates attempting to get the certification to perform certified translations in 24 languages. The conclusions of the entire study are rather soft than definitive. It appears that the criteria of evaluation and arithmetically expressed results of exams corroborate the validity of the assessment system adopted by the State Examination Board as stipulated in relevant legal regulations. Certain reservations as to the existing system might be voiced with regard to 'pass 
limits' in the written part of the exam, where the current 150 points could possibly be reduced to 140 . However, this 'candidate-friendly' postulate may be counterbalanced by a more conservative stance, according to which 150 points should be kept as pass reference score. This postulate is further supported by potentially highly negative social and legal effects of defective translations - the fact, which should rather promote assessment rigour than flexibility by the Board. A separate issue, probably worth a more systematic reflection, is whether there should be a unified examination conducted for sworn translators and interpreters (as it is now), or two separate examinations should be proposed. As there are equally strong arguments for and against the said separation, the issue remains as yet unresolved.

Keywords: examination for sworn translators and interpreters, the Gaussian distribution, examination pass rates 
